\title{
THE INFLUENCE OF INFORMATIVE MATERIAL OVER AWARENESS AND OPINION ABOUT ORGAN DONATION ON BRAZILIAN UNDEGRADUATE STUDENTS
}

\author{
Eduardo Riccetto*, Ilka F.S.F. Boin
}

\begin{abstract}
Objective: To assess the influence of exposure to informative material on the subject of organ donation and shifts in the trend of answers of undergraduate students to a standardized questionnaire, comparatively to the answers of a control group Methods: Both compared study groups received the same 20 multiple-choice questionnaire about one's technical knowledge and opinion about organ donation. Only the experimental group was also granted informative material on the subject. Students were randomly assigned to study groups. An Odds ratio was used to quantify the impact of the informative material on the subject's answers. Results: The questionnaire and attachments were e-mailed to 16,675 university students and answered by 895 . Mean age was 23 years old. Respondents were mainly female (65\% of total). There were differences on the answer pattern of the two groups on 6 out of 13 questions $(p<0,05)$. The experimental group tended to answers that expressed a better technical knowledge of the process of organ donation, as well as a more positive opinion to consenting to organ donation upon death of oneself or family members. Conclusion: Differences in the response pattern between the two compared groups indicate that the access to informative material plays an important role in establishing a good knowledge base and favorable opinion on the subject of organ donation.
\end{abstract}

Key words: Organ Donation, Undergraduate Students, Awareness

\section{Introduction}

Literature records on the effectiveness of informative campaigns at shifting opinion and technical knowledge of young adults on regards to organ donation are scarce. This project aimed to assess the influence of exposure to informative material on the subject of organ donation and shifts in the trend of answers of undergraduate students to a standardized questionnaire, comparatively to the answers of a control group to the same questionnaire.

\section{Results and Discussion}

Both study groups were randomly assigned and receveived the same 20 multiple-choice questionnaire about one's technical knowledge and opinion about organ donation. Only the experimental group was also granted access to informative material on the subject. An Odds ratio was used to quantify the impact of the informative material on the subject's answers.

The questionnaire was e-mailed to 35.878 students, and answered by 895 . Mean age of respondants was 23 years old. Respondents were mainly female ( $65 \%$ of total), had parentes that graduated in university $(44 \%)$, catholic $(30 \%)$, and never intereacted with a family member involved in the process of receving or donating organs $(90 \%)$.

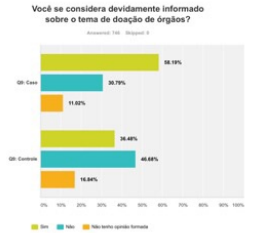

Figure 1: Example of a change in response pattern between studied groups
There were differences on the answer pattern of the two groups on 6 out of 13 questions $(p<0,05)$. The experimental group tended to answers that expressed a better technical knowledge of the process of organ donation, and a more favorable opinion on the matter as seen on table 1 .

Table 1: Changes in the answer patter in one of the questions studied

\begin{tabular}{|c|c|c|}
\hline Question & Odds Ratio & . $P$ \\
\hline $\begin{array}{l}\text { Você temeria que um ente querido doador, } \\
\text { diagnosticado com Morte Encefálica, possa nào } \\
\text { estar morto? }\end{array}$ & 0,71158 & 0,02993 \\
\hline $\begin{array}{l}\text { Vocé se considera devidamente informado sobre o tema } \\
\text { de doaçăo de órgâas? }\end{array}$ & 2,2794 & $1,729 \mathrm{E}-07$ \\
\hline $\begin{array}{l}\text { Vocé temeria que um ente querido doador, diagnosticado } \\
\text { com Morte } \\
\text { Encefalica, possa ndo estar morto? }\end{array}$ & 0,566 & 0,0027347 \\
\hline $\begin{array}{l}\text { Vocé recebe a noticia de que um de seus familiares } \\
\text { faleceu no hospital. O mesmo náo deixou claro o desejo } \\
\text { de doar orgáos. Caso voce fosse responsável pela } \\
\text { decisâo, autorizaria a doação? }\end{array}$ & 0,69398 & 0,04683 \\
\hline 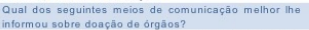 & 1,6531 & 0.0016601 \\
\hline $\begin{array}{l}\text { Um familiar the conta que deseja ser doador de órgáos } \\
\text { após a morte, porém nâo sabe como atestar seu } \\
\text { interesse. Como voce o aconselharia? }\end{array}$ & 2,1675 & $1,68 \mathrm{E}-06$ \\
\hline Conclu & & \\
\hline
\end{tabular}

The differences found in the response patterns of respondents between the two compared groups indicate that the access to informative material plays an important role in establishng a good knlowledge base and favourable opionin on the subjet of organ donation.

\section{Acknowledgements}

This study has received financial support from the Conselho Nacional de Desenvolvimento Científico e Tecnológico (CNPq)

\footnotetext{
Assoacią̧ão Brasileira de Transplante de Órgãos. Dimensionamento dos Transplantes no Brasil e em cada estado. 2016 Mar 8::2 Barcellos FC, Araujo CL, da Costa JD. Organ donation: a population-based study. Clin Transplant. 2005 Feb;19(1):33-7 3. Boland KP, Baker KQ, Nicholson AB. College students perceptions about organ donation. The Journal of Heart and Lun (24): $24: 3133$ 作 Transplantation Proceedings. 2002 Sep; 34(6):2009-11.

5.Tessmer MG, Mielke GL, Barcellos FC, Moraes BP. Doação de órgäos: opiniảo e entendimento sobre morte encetalilica de estudantes universitärios. J Bras Transpl. 201

G Galvao FHF, Caires RA, Azevedo-Neto RS, Mory EK, Figueira ERR, Otsuzi TS, et al. Attitude and opinion of medical students about organ donation and transplantation. Revista da Associação Medica Brasileira. Associaçāo Médica Brasileira; 2007 O

7. Santos Z, Capistrano AP, Oliveira V. Doaçăo de Órgàos sob a Optica do Estudante Universitärio. JBT. 2004.
} 